Bull. Chem. Soc. Ethiop. 2021, 35(2), 217-228.

(c) 2021 Chemical Society of Ethiopia and The Authors

ISSN 1011-3924

DOI: https://dx.doi.org/10.4314/bcse.v35i2.1

Printed in Ethiopia

Online ISSN 1726-801X

\title{
LEVELS OF SELECTED METALS IN THE FRUITS OF A WILD EDIBLE PLANT (RUBUS STEUDNERI SCHWEINF) AND ITS UNDERLYING SOIL
}

\author{
Zelalem Pawlos ${ }^{1}$, Bhagwan Singh Chandravanshi ${ }^{1 *}$, Weldegebriel Yohannes ${ }^{1}$ and Asamene \\ Embiale $^{2}$ \\ ${ }^{1}$ Department of Chemistry, College of Natural and Computational Sciences, \\ Addis Ababa University, P.O. Box 1176, Addis Ababa, Ethiopia \\ ${ }^{2}$ Department of Chemistry, Woldia University, P.O. Box 400, Woldia, Ethiopia
}

(Received November 11, 2020; Revised September 8, 2021; Accepted September 11, 2021)

\begin{abstract}
This study was focused on investigation of amount of macro and trace metals present in the fruit samples of Rubus steudneri Schweinf plant and its underlying soil samples collected from Chencha, Dega Damot and Fiche areas of Ethiopia. The levels of selected metals ( $\mathrm{K}, \mathrm{Ca}, \mathrm{Mg}, \mathrm{Fe}, \mathrm{Mn}, \mathrm{Zn}, \mathrm{Cu}, \mathrm{Cd}$, and $\mathrm{Pb}$ ) were determined by microwave plasma-atomic emission spectroscopy using wet-digestion technique. The validity of the method was checked by the analysis of spiked samples whose recovery was found in the range of $90.5-108 \%$. The mean concentration of metals $\mathrm{K}, \mathrm{Mg}, \mathrm{Fe}, \mathrm{Ca}, \mathrm{Zn}, \mathrm{Cu}, \mathrm{Mn}, \mathrm{Pb}$ and $\mathrm{Cd}$ in the fruit samples were found in the range of 9463-9836, 973-1099, 328-639, 2663-2999, 29.6-52.8, 6.70-8.87, 128-639, 2.54-3.37 and 0.26-1.21 $\mathrm{mg} / \mathrm{kg}$, respectively. The level of metals in the soil samples were found in the range of $1375-1790,1169-1388$, $74951-104145,2079-3502,122-149,21.6-40.4,1359-1931,7.11-17.0$ and $\mathrm{ND} \mathrm{mg} / \mathrm{kg}$, respectively. The accumulation factor values for the tested metals were found in the range of $0.003(\mathrm{Fe})-7.07(\mathrm{~K})$. The Rubus steudneri Schweinf fruit is good source of essential metals and useful to human health. However, the concentration of toxic metals viz. $\mathrm{Cd}$ and $\mathrm{Pb}$ were found in amount excess as compared to $\mathrm{WHO} / \mathrm{FAO}$ maximum permissible limit.
\end{abstract}

KEY WORDS: Rubus steudneri Schweinf, Wild edible plant, Fruit, Heavy metals, Soil, Ethiopia

\section{INTRODUCTION}

Plants are the main sources for animal and human nutrition. Depending on different climates and cultures, a number of plant species have been used for different purposes. From past to present, a number of wild plants, which are known to be edible, are being used as food sources [1]. The wild edible plants may be seasonal and can have more nutritional value than those grown in farmlands. These are fresh and more tasteful. Wild edible plants are rich sources of various vitamins, minerals, fibres, antioxidants, etc. which not only provide several health benefits but reduces the risk of several diseases like diabetes, cancer, coronary heart disease, neurodegenerative ailment and aging as well [2-4]. Despite of this, some plants considered to be edible could have poisonous, bitter, woody, and hairy parts also. Therefore, it is very important to identify which plant is an edible one and which could have disastrous consequences [2]. For example, toxic metals taken through wild edible plant might pose a significant health risks to all living organisms upon long term exposures [5]. Because of their non-biodegradability, long biological half-lives, potential to accumulate in different body parts added by their solubility in water, the possibility of these toxic metals causing deleterious health effects is quite high even at low concentration levels. They are known to have damaging effects on man and animals since there is no good mechanism for their elimination from the body [6]. In addition, soil-planthuman (food chain) and soil-human (incidental soil ingestion) relationship are the two most important pathways through which human exposure to toxic metals takes place. Out of the two,

${ }^{*}$ Corresponding author. E-mail: bscv2006@yahoo.com

This work is licensed under the Creative Commons Attribution 4.0 International License 
the soil-to-plants transfer is the key component of human exposure to metals [7]. Therefore, analysis of the level of metals in soil is important.

The environmental compartments including soil, water and air contain several sources of nutrients for any plants. Though plants are perfectly selective to essential nutrients, they may take up heavy metals that are toxic even at low level. From the environmental compartments used as sources of nutrients, soil is considered a critical environment as it accumulates pollutants (like heavy metals) that can be dispersed in it, both naturally and by various anthropogenic activities. Metals present in the soil fractions vary in degree of mobility. Their bioavailability is regulated by soil properties (physical, chemical and biological processes) and the interactions between them. For example, with increasing $\mathrm{pH}$, contents of organic matter and clay as well as the solubility of most metals are decreased due to their increased tendencies for adsorption $[8,9]$. Plants assimilate metals through the roots. The direct contact between the plant roots and soil allows most metals to enter the plant tissue through uptake of water and nutrients by plants, ion exchange at cell wall and other complicated metabolic mechanisms [10]. Once metals taken up by roots, they can either be stored by the roots or transported to other parts of the plant. Thus, plants take up metals and accumulate them in their edible and nonedible parts in quantities high enough to cause risks both to animals and human beings consuming these metal rich plants [6]. The metals taken by the plant are classified as essential and non-essential, based on their importance. The metals like $\mathrm{K}, \mathrm{Mg}, \mathrm{Ca}, \mathrm{Mn}, \mathrm{Fe}, \mathrm{Co}, \mathrm{Cu}$, and $\mathrm{Zn}$ are classified as essential as these are very important for growth and health while $\mathrm{Cd}, \mathrm{Ag}$, $\mathrm{Co}, \mathrm{Pb}$, etc. are nonessential. Based on the amount needed, the nutritionally important minerals are grouped into macro-minerals and trace-minerals. Elements, such as $\mathrm{Mn}, \mathrm{Fe}, \mathrm{Co}, \mathrm{Cu}, \mathrm{Zn}, \mathrm{Se}$, $\mathrm{Mo}, \mathrm{F}$ and I are essential trace elements, while elements like $\mathrm{Ca}, \mathrm{Mg}$ and $\mathrm{K}$ are grouped under essential macro-minerals [11].

Many wild plants are in use in Ethiopia mainly for house building and household utensils, clothing, food, soap, medicine, and magic and ritual purposes. Wild plants have, also, been used as sources of food both at times of plenty and food shortage by pastoral groups, farming communities, monks and nuns who live in isolated monasteries and churches in rural areas [12]. Previous report showed that 560 out of 7000 higher plants found in Ethiopia are edible [13]. In addition, peoples in western part of Ethiopia, specifically in Benishangul-Gumuz region, use wild edible plants for solving of severe poverty and food insecurity conditions [14]. Rubus steudneri Schweinf is one of prominent plants used by most of the Ethiopian for food as well as medicine $[15,16]$. Rubus steudneri Schweinf fruits in Ethiopia are common element of human diet due to great taste value, the content of easily available sugars, mineral salts and vitamins [17]. It has also been used as food in other parts of the world, such as Poland.

The plant Rubus steudneri Schweinf, shown in Figure 1, belongs to the family Rosaceae. It is a scandent shrub characterized by deeply furrowed stems that are greyish-tomentose and covered with stellate hairs or sometimes with prickles. The leaves are trifoliolate, doubly serrate, glabrate above and densely whitish-tomentose below. Inflorescence is a terminal panicle, muchbranched and the branches are glandular-tomentose. Petals are obovate-oblong, purplish and twice as long as the calyx [18].

The plant is utilized ethnobotanically as food as well as medicine. The decoction made from the roots is used as a remedy for indigestion and gastritis. The plant is also used for treating diabetes mellitus. Different parts of the plant are medicinally useful for treating rheumatism, stomachache, diarrhea and cough $[15,16]$. Besides, the plant is also used for ornamental purposes, as fence and for house construction [19]. Literatures show that the plant exhibits bioactivities such as antioxidant [20] and antimicrobial [18].

A few studies have been reported on the levels of metals in fruits of cactus pear [21]; fennel [22]; banana, grape, guava, mandarin and orange [23]; apple [24]; Ficus sur Forssk [25]; seeds of korarima [26] and fenugreek [27] in Ethiopia. Still there are not many studies on level of macro, micro and toxic metals in wild edible plants, in general, particularly in Rubus steudneri 
Schweinf fruits. Therefore, the present study was focused on the determination of macro (K, $\mathrm{Mg}$ and $\mathrm{Ca}$ ), micro ( $\mathrm{Zn}, \mathrm{Fe}, \mathrm{Cu}$, and $\mathrm{Mn})$ and toxic $(\mathrm{Pb}$ and $\mathrm{Cd})$ metals in Rubus steudneri Schweinf fruits and the soils samples from the areas where this plant is grown by microwave plasmaatomic emission spectrometry. Both fruits and soil samples were collected from different parts of Ethiopia.

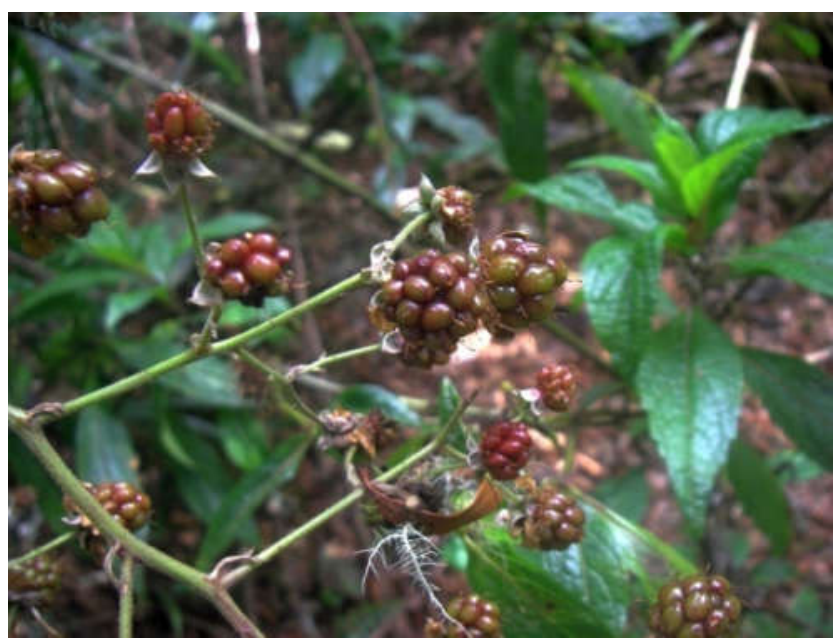

Figure 1. Rubus steudneri Schweinf plant with edible fruits.

\section{EXPERIMENTAL}

Description of sampling area

Fiche (Oromiya region), Dega Damot (Amahara region) and Chencha (Southern Nations, Nationality and Peoples Region) were chosen as sampling sites. The selection of these sampling regions was due to the wide availability of Rubus steudneri Schweinf fruits and the prevalence of its consumption by most of the inhabitants in these regions. The geographical locations (latitude, longitude, and elevation) of various sampling sites are given in Table 1.

Table 1. Geographical location, height, and distance of sampling sites from Addis Ababa.

\begin{tabular}{|c|c|c|c|c|}
\hline Sampling site & Latitude & Longitude & Elevation $(\mathrm{m})$ & Distance $(\mathrm{km})$ \\
\hline Fiche & $9^{\circ} 48^{\prime} \mathrm{N}$ & $38^{\circ} 44^{\prime} \mathrm{E}$ & 2738 & 126 \\
\hline Dega Damot & $11^{\circ} 05^{\prime} \mathrm{N}$ & $37^{\circ} 25^{\prime} \mathrm{E}$ & 1917 & 552 \\
\hline Chencha & $6^{\circ} 15^{\prime} \mathrm{N}$ & $37^{\circ} 34^{\prime} \mathrm{E}$ & 2732 & 478 \\
\hline
\end{tabular}

Sample collection and preparation

The bulk fruit sample was collected in polyethylene bags from five different locations in each sampling site. Vinyl gloves were used during the sampling to avoid hand contact to the sample. The samples were transported to the Analytical Laboratory of Chemistry Department of Addis Ababa University immediately after the sampling was over. The fruit samples were washed with tap water and then with double distilled water to eliminate adsorbed dust and particulate matters. 
The fruit samples were cut and chopped into small pieces using a plastic knife in order to facilitate drying. The samples were air-dried for six days and further dried in a hot air oven at $50-60{ }^{\circ} \mathrm{C}$ for $24 \mathrm{~h}$ to remove moisture and maintain constant mass. The dried samples were ground into powder using commercial mortar and pestle and sieved to $0.425 \mathrm{~mm}$ mesh size. The sieved samples were stored in the polyethylene bags and kept in desiccators until the time of digestion.

The bulk soil sample was also collected from the base of the uprooted plant by auger and packed in polyethylene bags. Each soil sample was air dried at ambient temperature for three days and ground into powder using commercial mortar and pestle and sieved to $0.425 \mathrm{~mm}$ mesh. The sieved soil samples were stored in the polyethylene bags and placed in desiccators until the time of digestion.

\section{Soil sample preparation for determination of $\mathrm{pH}, \mathrm{EC}$ and $\mathrm{OM}$}

The $\mathrm{pH}$, electrical conductivity (EC) and soil organic matter $(\mathrm{OM})$ content were determined using the method reported by Boke et al. [7]. $5 \mathrm{~g}$ of air-dried soil $(<0.425 \mathrm{~mm})$ was weighed and transferred to a $100 \mathrm{~mL}$ beaker to which $12.5 \mathrm{~mL}$ distilled water was added. Then, the mixture was stirred and the $\mathrm{pH}$ and $\mathrm{EC}$ were measured after allowing the suspension to stand for $10 \mathrm{~min}$ at room temperature using $\mathrm{pH}$ meter and conductivity meter.

The soil organic matter $(\mathrm{OM})$ was determined using the method of loss on ignition. $5 \mathrm{~g}$ of the soil sample was dried in an oven at $100{ }^{\circ} \mathrm{C}$ for $15 \mathrm{~min}$ in a pre-weighed crucible. Then, the crucible with the soil was placed in a muffle furnace and heated at $500{ }^{\circ} \mathrm{C}$ for $3.5 \mathrm{~h}$. The sample was taken out from the furnace and was allowed to cool in desiccator. The sample was reweighed and the percentage of organic matter content was calculated.

\section{Optimization of digestion procedure for fruit and soil samples}

Different digestion procedures for the fruit samples and the soil samples were carried out using $\mathrm{HNO}_{3}, \mathrm{HClO}_{4}$ and $\mathrm{HCl}$ acid mixtures by varying volumes, digestion time and digestion temperature. This procedure was developed with some modification of the procedure in literature used to determine the metal content of wild edible plant fruit samples by FAAS [7]. Optimized procedures were selected based on the usage of lesser reagent volume, shorter digestion time and reasonable mild temperature for obtaining clear colorless solutions of the resulting digests.

$0.5 \mathrm{~g}$ of powdered and homogenized fruit sample was weighed and transferred to a $250 \mathrm{~mL}$ round bottom flask. To this, different volumes of $\mathrm{HNO}_{3}$ and $\mathrm{HClO}_{4}$ at specified proportions $(\mathrm{v} / \mathrm{v})$ were added and digested at different temperatures of $150 / 180 / 210 / 240 / 270 / 300{ }^{\circ} \mathrm{C}$ for different duration of time $(60 / 90 / 120 / 150 / 180 \mathrm{~min})$. The optimized procedure was determined based on the formation of a clear colorless solution. The digested solutions were allowed to cool and $5 \mathrm{~mL}$ of distilled water was added to dissolve the precipitate formed on cooling and gently swirled and filtered into $50 \mathrm{~mL}$ volumetric flask through Whatman number 42 filter paper. The clear solution then was made up to $50 \mathrm{~mL}$ with distilled water and stored for analysis by microwave plasma-atomic emission spectroscopy. Similar optimization procedure was also used for soil sample. The details of the optimization of digestion procedures for fruit and soil samples are given in Table 2 .

From Table 2, $4 \mathrm{~mL}$ of $3: 1(\mathrm{v} / \mathrm{v})$ of $\mathrm{HNO}_{3}$ and $\mathrm{HClO}_{4}, 240{ }^{\circ} \mathrm{C}$ and $2.5 \mathrm{~h}$ were found as optimum for digestion of $0.5 \mathrm{~g}$ of powdered and homogenized fruit sample and $5 \mathrm{~mL}$ of $3: 1: 1$ ratio of $\mathrm{HNO}_{3}, \mathrm{HCl}$ and $\mathrm{HClO}_{4}, 270{ }^{\circ} \mathrm{C}$ and $2 \mathrm{~h}$ were optimum for the digestion of $0.5 \mathrm{~g}$ soil sample. 
Table 2. Attempted digestion procedures for Rubus steudneri Schweinf fruit and soil samples.

\begin{tabular}{|c|c|c|c|c|c|c|c|}
\hline \multicolumn{4}{|c|}{ Fruit sample } & \multicolumn{4}{|c|}{ Soil sample } \\
\hline $\begin{array}{l}\text { Volume ratio } \\
\left(\mathrm{HNO}_{3}:\right. \\
\left.\mathrm{HClO}_{4}\right)\end{array}$ & $\begin{array}{c}\text { Digestion } \\
\text { temperature } \\
\left({ }^{\circ} \mathrm{C}\right)\end{array}$ & $\begin{array}{c}\begin{array}{c}\text { Digestion } \\
\text { time }(\mathrm{h})\end{array} \\
\end{array}$ & Observations & $\begin{array}{c}\text { Volume ratio } \\
\left(\mathrm{HNO}_{3}: \mathrm{HClO}_{4}:\right. \\
\mathrm{HCl})\end{array}$ & \begin{tabular}{|c|} 
Digestion \\
temperature \\
$\left({ }^{\circ} \mathrm{C}\right)$ \\
\end{tabular} & $\begin{array}{c}\text { Digestion } \\
\text { time }(\mathrm{h})\end{array}$ & Observations \\
\hline $1: 1(2 \mathrm{~mL})$ & \multirow[t]{5}{*}{240} & \multirow[t]{5}{*}{3} & Clear yellow & $1: 1: 1(3 \mathrm{~mL})$ & \multirow[t]{8}{*}{240} & \multirow[t]{8}{*}{3} & Clear yellow \\
\hline $2: 1(3 \mathrm{~mL})$ & & & Clear light yellow & 2:1:1 (4 mL) & & & Clear yellow \\
\hline $1: 2(3 \mathrm{~mL})$ & & & \begin{tabular}{|l|} 
Clear light yellow \\
\end{tabular} & $1: 2: 1(4 \mathrm{~mL})$ & & & \begin{tabular}{|l|} 
Clear yellow \\
\end{tabular} \\
\hline $2: 2(4 \mathrm{~mL})$ & & & Clear light yellow & $1: 1: 2(4 \mathrm{~mL})$ & & & $\begin{array}{l}\text { Clear light } \\
\text { yellow }\end{array}$ \\
\hline 3:1 (4 mL) & & & \begin{tabular}{|l|}
$\begin{array}{l}\text { Clear colorless } \\
\text { solution }\end{array}$ \\
\end{tabular} & $2: 2: 1(5 \mathrm{~mL})$ & & & \begin{tabular}{|l|} 
Clear light \\
yellow
\end{tabular} \\
\hline \multirow[t]{3}{*}{$3: 1(4 \mathrm{~mL})$} & 180 & \multirow[t]{3}{*}{3} & Clear yellow & $1: 2: 2(5 \mathrm{~mL})$ & & & $\begin{array}{l}\text { Clear light } \\
\text { yellow }\end{array}$ \\
\hline & 210 & & Clear light yellow & $2: 1: 2(5 \mathrm{~mL})$ & & & $\begin{array}{l}\text { Clear light } \\
\text { yellow }\end{array}$ \\
\hline & 240 & & $\begin{array}{l}\text { Clear colorless } \\
\text { solution }\end{array}$ & 3:1:1 (5 mL) & & & \begin{tabular}{|l|}
$\begin{array}{l}\text { Clear colorless } \\
\text { solution }\end{array}$ \\
\end{tabular} \\
\hline \multirow[t]{3}{*}{$3: 1(4 \mathrm{~mL})$} & \multirow[t]{3}{*}{240} & $1: 30$ & Clear yellow & $3: 1: 1(5 \mathrm{~mL})$ & 180 & \multirow[t]{4}{*}{3} & Clear yellow \\
\hline & & 2 & Clear light yellow & 3:1:1 (5 mL) & 210 & & Clear yellow \\
\hline & & 2:30 & $\begin{array}{l}\text { Clear colorless } \\
\text { solution }\end{array}$ & & 240 & & \begin{tabular}{|l}
$\begin{array}{l}\text { Clear colorless } \\
\text { solution }\end{array}$ \\
\end{tabular} \\
\hline & & & & & 270 & & \begin{tabular}{|l|}
$\begin{array}{l}\text { Clear colorless } \\
\text { solution }\end{array}$ \\
\end{tabular} \\
\hline & & & & 3:1:1 (5 mL) & \multirow[t]{2}{*}{270} & $1: 30$ & \begin{tabular}{|l|}
$\begin{array}{l}\text { Clear light } \\
\text { yellow }\end{array}$ \\
\end{tabular} \\
\hline & & & & & & 2 & $\begin{array}{l}\text { Clear colorless } \\
\text { solution }\end{array}$ \\
\hline
\end{tabular}

Analysis of metals using MP-AES

Four series of working standards for each metal of interest (i.e. $\mathrm{K}, \mathrm{Ca}, \mathrm{Mg}, \mathrm{Mn}, \mathrm{Cd}, \mathrm{Zn}, \mathrm{Pb}, \mathrm{Fe}$, and $\mathrm{Cu}$ ) were prepared from an intermediate $100 \mathrm{mg} / \mathrm{L}$ standard solution. Calibration curves were constructed for each metal, which showed correlation coefficients $(r>0.99)$. The metals in the fruit samples and the soil samples were determined by microwave plasma-atomic emission spectroscopy (MP-AES) (Agilent 4200 MP-AES, USA) with nitrogen supplied from an Agilent 4107 nitrogen generator. The sample introduction system consisted of a micro mist nebulizer and double-pass glass cyclonic spray chamber. An external gas control module (EGCM) accessory and auto sampler were used. The MP-AES was controlled using the intuitive MP Expert software, which recommends wavelengths for the selected elements and automatically sets the nebulizer flow rate and EGCM settings. Auto background correction was used to resolve the element emission line from the organic matrix. The sample introduction system consisted of PVC peristaltic pump tubing, a single-pass glass cyclonic spray chamber and the One Neb nebulizer. The Agilent MP Expert software was used to automatically subtract the background signal from the analytical signal. The typical specification of method used during MP-AES is given in Table 3.

\section{Evaluation of analytical method}

The efficiency of the analytical method used in the study was evaluated by recovery test. Six replicate blank samples were digested following the same procedure for fruit samples and soil samples. The mean and standard deviations of the blanks were calculated to determine the 
method detection limit (MDL) and it was expressed as $3 \mathrm{~S}_{\text {blank }}$ where $\mathrm{S}$ is the standard deviation of the blank sample [7].

Table 3. Agilent 4200 MP-AES operating conditions.

\begin{tabular}{|l|c|c|c|c|c|c|c|c|c|}
\hline Parameters & $\mathrm{K}$ & $\mathrm{Mg}$ & $\mathrm{Ca}$ & $\mathrm{Mn}$ & $\mathrm{Fe}$ & $\mathrm{Cu}$ & $\mathrm{Zn}$ & $\mathrm{Cd}$ & $\mathrm{Pb}$ \\
\hline Wavelength (nm) & 766.5 & 285.2 & 422.7 & 403.1 & 372.0 & 324.8 & 213.9 & 228.8 & 405.8 \\
\hline Background correction & Auto & Auto & Auto & Auto & Auto & Auto & Auto & Auto & Auto \\
\hline EGCM setting & High & High & High & High & High & High & High & High & High \\
\hline Replicates & 3 & 3 & 3 & 3 & 3 & 3 & 3 & 3 & 3 \\
\hline Pump speed (rpm) & 15 & 15 & 15 & 15 & 15 & 15 & 15 & 15 & 15 \\
\hline Blank subtraction & On & On & On & On & On & On & On & On & On \\
\hline Stabilization time (s) & 22 & 22 & 15 & 20 & 16 & 22 & 20 & 22 & 22 \\
\hline Sample uptake time (s) & 29 & 28 & 27 & 28 & 30 & 30 & 28 & 28 & 28 \\
\hline Sample uptake fast pump & On & On & On & On & On & On & On & On & On \\
\hline Rinse time (s) & 10 & 10 & 10 & 10 & 10 & 10 & 10 & 10 & 10 \\
\hline Read time (s) & 3 & 3 & 3 & 3 & 3 & 3 & 3 & 3 & 3 \\
\hline Nebulizer flow (L/min) & 1 & 0.9 & 0.9 & 0.9 & 0.65 & 0.7 & 0.95 & 0.5 & 0.9 \\
\hline
\end{tabular}

A recovery test was carried out by spiking pre-analyzed samples. Except for $\mathrm{K}$ and $\mathrm{Ca}$ metals, each of the target elements was spiked at $50 \%$ of the initial concentrations of the respective element in the original sample. Thus, 275, 32, 160, 2.2, 13, 0.22, 971, 750 and 1.68 $\mu \mathrm{L}$ of $1000 \mathrm{mg} / \mathrm{L} \mathrm{Mg}, \mathrm{Mn}, \mathrm{Fe}, \mathrm{Cu}, \mathrm{Zn}, \mathrm{Cd}, \mathrm{K}, \mathrm{Ca}$, and $\mathrm{Pb}$ were spiked to $0.5 \mathrm{~g}$ fruit sample, respectively. The spiked fruit and soil samples were digested in triplicate following the same procedure used for digestion of the fruit samples and the soil samples and percentage recovery was determined. The percentage recoveries were found in the range of $90.5-109 \%$ for all the metals. The MDL was found to be low enough to detect the metals at trace levels in both the fruit samples and soil samples. The method detection limits and percentage recoveries are given in Table 4 and Table 5, respectively.

Table 4. Method detection limits (MDLs) for the plant fruit and its soil sample.

\begin{tabular}{|c|c|c|}
\hline \multirow{2}{*}{ Metal } & \multicolumn{2}{|c|}{ Method detection limits } \\
\cline { 2 - 3 } & Fruit sample $(\mathrm{mg} / \mathrm{kg})$ & Soil sample $(\mathrm{mg} / \mathrm{kg})$ \\
\hline $\mathrm{K}$ & 2.4 & 0.82 \\
\hline $\mathrm{Ca}$ & 1.9 & 1.5 \\
\hline $\mathrm{Mg}$ & 0.70 & 0.57 \\
\hline $\mathrm{Zn}$ & 0.50 & 0.15 \\
\hline $\mathrm{Cu}$ & 0.97 & 1.8 \\
\hline $\mathrm{Fe}$ & 1.3 & 0.96 \\
\hline $\mathrm{Mn}$ & 1.6 & $\mathrm{ND}$ \\
\hline $\mathrm{Cd}$ & 0.13 & 0.95 \\
\hline $\mathrm{Pb}$ & 0.12 & 0.25 \\
\hline
\end{tabular}

Statistical analysis of data

The data obtained was analyzed by a computer program using Microsoft Excel 2007. One-way ANOVA $(p=0.05)$ was used to assess the statistical level of significance of the difference between and within the data obtained with samples from different sources. Pearson correlation was evaluated to assess the sources of metals. 
Table 5. Recovery test results for fruit sample.

\begin{tabular}{|c|c|c|c|c|c|}
\hline Metal & $\begin{array}{c}\text { Concentration } \\
\text { in sample } \\
(\mathrm{mg} / \mathrm{kg})\end{array}$ & $\begin{array}{c}\text { Amount } \\
\text { added } \\
(\mathrm{mg} / \mathrm{kg})\end{array}$ & $\begin{array}{c}\text { Concentration in the } \\
\text { spiked sample } \\
(\mathrm{mg} / \mathrm{kg})\end{array}$ & $\begin{array}{c}\text { Amount } \\
\text { recovered } \\
(\mathrm{mg} / \mathrm{kg})\end{array}$ & $\begin{array}{c}\text { Recovery } \\
(\%)\end{array}$ \\
\hline $\mathrm{Mg}$ & 1099 & 549 & 1686 & 587 & $107 \pm 2.1$ \\
\hline $\mathrm{Mn}$ & 128 & 64 & 189 & 61 & $95.3 \pm 5.2$ \\
\hline $\mathrm{Fe}$ & 639 & 319 & 977 & 338 & $106 \pm 4$ \\
\hline $\mathrm{Cu}$ & 8.87 & 4.44 & 12.9 & 4.03 & $90.8 \pm 2.1$ \\
\hline $\mathrm{Zn}$ & 52.8 & 26.4 & 77.1 & 24.3 & $92 \pm 3.1$ \\
\hline $\mathrm{Cd}$ & 0.87 & 0.44 & 1.30 & 0.43 & $97.7 \pm 3$ \\
\hline $\mathrm{K}$ & 9717 & 1943 & 11475 & 1758 & $90.5 \pm 1.7$ \\
\hline $\mathrm{Ca}$ & 2999 & 600 & 3635 & 636 & $106 \pm 2$ \\
\hline $\mathrm{Pb}$ & 3.37 & 1.67 & 5.19 & 1.82 & $109 \pm 2$ \\
\hline
\end{tabular}

\section{RESULTS AND DISCUSSION}

\section{Characteristics of soil}

The highest amounts of \% organic matter and electrical conductivity were obtained in the soil of Dega Damot, whereas highest $\mathrm{pH}$ was found in Chencha soil. The lowest EC and \% OM were found in Fiche and Chencha, respectively. The lowest $\mathrm{pH}$ was obtained at Dega Damot. The results are presented in Table 6.

Table 6. The $\mathrm{pH}, \mathrm{EC}$ and $\mathrm{OM}$ of the soil samples (mean $\pm \mathrm{SD}, \mathrm{n}=3$ ).

\begin{tabular}{|c|c|c|c|}
\hline Sampling area & $\mathrm{pH}$ & $\mathrm{EC}\left(\mathrm{mSm}^{-1}\right)$ & OM (\%) \\
\hline Chencha & $5.81 \pm 0.05$ & $10.3 \pm 0.37$ & $15.1 \pm 0.43$ \\
\hline Dega Damot & $5.54 \pm 0.13$ & $13.5 \pm 0.42$ & $16.6 \pm 0.48$ \\
\hline Fiche & $5.74 \pm 0.03$ & $7.84 \pm 0.02$ & $15.5 \pm 0.48$ \\
\hline
\end{tabular}

Studies have shown that the higher the soil organic matter content, the higher the ability of that soil to retain metals within it. This is due to the adsorption reaction of metals on it. Accordingly, the bioavailability of metals in soil for the Rubus steudneri Schweinf grown were found in decreasing order of Chencha $>$ Fiche $>$ Dega Damot.

The $\mathrm{pH}$ found in soil ranged 5.54-5.81 which is not considered as optimum $\mathrm{pH}$ range for the most plants. Since, soils with a pH below 6.0 are more likely to be deficient in some available nutrients. $\mathrm{Ca}, \mathrm{Mg}$, and $\mathrm{K}$ are especially deficient in acid soils [28].

Soils can be classified into three groups based on the level of EC as good soil health (EC range of $0-100 \mathrm{mS} / \mathrm{m}$ ), non-saline (EC less than $100 \mathrm{mS} / \mathrm{m}$ ) and saline (EC more than 100 $\mathrm{mS} / \mathrm{m}$ ) [29]. Accordingly, the soil EC of the study areas is within the range of 7.84 to $13.5 \mathrm{~ms} / \mathrm{m}$ which indicates that the soil environment is good for the plant growth.

\section{Level of metals in Rubus steudneri Schweinf fruit and soil samples}

The results on level of metals are presented in Table 7. The level of $\mathrm{K}, \mathrm{Mg}, \mathrm{Ca}, \mathrm{Mn}, \mathrm{Fe}, \mathrm{Cu}, \mathrm{Zn}$, $\mathrm{Cd}$ and $\mathrm{Pb}$ in the fruit samples from the three sampling sites were found in the range of 9463-9836, 973-1099, 2663-2999, 128-187, 328-639, 6.7-8.87, 29.6-52.8, 0.26-1.21, and $2.54-3.37 \mathrm{mg} / \mathrm{kg}$, respectively and the levels of metals in the soil samples were found in the range of 1375-1790, 1169-1388, 2079-3502, 1359-1931, 74951-104145, 21.6-40.4, 122-149, $\mathrm{ND}$, and 7.11-17.0 $\mathrm{mg} / \mathrm{kg}$, respectively. The variation in the amount of the metal across the 
sampling site might be due to a number of physicochemical properties such as $\mathrm{pH}$, organic matter contents, cation exchange capacity, redox potential, soil texture and clay contents [30]. It should also be noted that although the Cd was not detected in the soil does not meant it is not present in the soil rather its concentration is very low. However, it has an accumulation capacity through long time in the plant parts that is why $\mathrm{Cd}$ was detected at trace levels in the fruit samples.

Of the metals in Rubus steudneri Schweinf fruits, the macro metals followed the pattern: K $>\mathrm{Ca}>\mathrm{Mg}$. The lower value of $\mathrm{Ca}$ from Dega Damot may be attributed to the lower $\mathrm{pH}$ (5.54) of soils of that area (indicating the presence of intensive leaching that the availability of $\mathrm{Ca}$ is decreased in these soils). The results further showed the pattern of micronutrient and toxic metals as: $\mathrm{Fe}>\mathrm{Mn}>\mathrm{Zn}>\mathrm{Cu}$ and $\mathrm{Pb}>\mathrm{Cd}$, respectively. The highest concentration of $\mathrm{Cd}$ in Rubus steudneri Schweinf fruit was obtained at Dega Damot, whereas its lowest concentration was seen at Fiche sampling site. It should be noted that Cd was not detected in the soil while it was detected at trace level in the fruit samples. The possible source of traces $\mathrm{Cd}$ in the fruit samples might be from the water. Furthermore, the maximum $\mathrm{Pb}$ concentration was obtained at Chencha. Thus, peoples who consume this fruit in the region where the toxic metals are high should care by not consuming high amount regularly.

Table 7. Concentration of metals $(\mathrm{mg} / \mathrm{kg})$ in Rubus steudneri Schweinf fruit and soil samples (mean $\pm \mathrm{SD}$, $\mathrm{n}=3$ ) and WHO/FAO Joint CODEX Alimentarius Commission maximum permissible levels [31].

\begin{tabular}{|c|c|c|c|c|c|c|c|}
\hline \multirow[t]{3}{*}{ Metal } & \multicolumn{7}{|c|}{ Levels of metal $(\mathrm{mg} / \mathrm{kg})$} \\
\hline & \multicolumn{3}{|c|}{ Fruit } & \multicolumn{3}{|c|}{ Soil } & \multirow{2}{*}{$\begin{array}{l}\text { WHO/FAO } \\
\text { level in fruit }\end{array}$} \\
\hline & Chencha & Dega Damot & Fiche & Chencha & Dega Damot & Fiche & \\
\hline $\mathrm{K}$ & $9717 \pm 16$ & $9836 \pm 14$ & $9463 \pm 20$ & $1375 \pm 11$ & $1659 \pm 9$ & $1790 \pm 8$ & - \\
\hline $\mathrm{Mg}$ & $1099 \pm 15$ & $973 \pm 22$ & $1091 \pm 21$ & $1388 \pm 7$ & $1169 \pm 8$ & $1178 \pm 8$ & - \\
\hline $\mathrm{Ca}$ & $2999 \pm 8$ & $2663 \pm 9$ & $2751 \pm 9$ & $3502 \pm 9$ & $2079 \pm 9$ & $2807 \pm 9$ & - \\
\hline $\mathrm{Mn}$ & $128 \pm 1$ & $158 \pm 1$ & $187 \pm 3$ & $1416 \pm 8$ & $1359 \pm 9$ & $1913 \pm 9$ & - \\
\hline $\mathrm{Fe}$ & $639 \pm 3$ & $328 \pm 4$ & $246 \pm 3$ & $74951 \pm 13$ & $104145 \pm 14$ & $97250 \pm 19$ & - \\
\hline $\mathrm{Cu}$ & $8.87 \pm 0.23$ & $6.7 \pm 0.53$ & $8.54 \pm 0.32$ & $40.4 \pm 3.1$ & $34.9 \pm 2.0$ & $21.6 \pm 2.0$ & 40 \\
\hline $\mathrm{Zn}$ & $52.8 \pm 1.3$ & $42.2 \pm 1.2$ & $29.6 \pm 2.2$ & $122 \pm 3.1$ & $135 \pm 5.1$ & $149 \pm 4.1$ & 50 \\
\hline $\mathrm{Pb}$ & $3.37 \pm 0.14$ & $2.54 \pm 0.12$ & $2.54 \pm 0.13$ & $13.2 \pm 0.4$ & $16.9 \pm 0.7$ & $7.11 \pm 0.71$ & 0.3 \\
\hline $\mathrm{Cd}$ & $0.87 \pm 0.05$ & $1.21 \pm 0.03$ & $0.26 \pm 0.02$ & ND & ND & ND & 0.2 \\
\hline
\end{tabular}

ND - not detected.

The level of Fe was much higher than the other metals in all the soil samples. The highest level of Fe was found in the soil of Dega Damot while the lowest level was found in the soil of Chencha. The distribution of macro metal levels in the soil sample showed that $\mathrm{Ca}, \mathrm{K}$ and $\mathrm{Mg}$ were the most abundant elements in the soil samples. The highest average concentration of $\mathrm{Ca}$ and $\mathrm{Mg}$ were noted for the soil of Chencha followed by Fiche. Mn concentration is highest in Fiche soil sample. The lowest concentration of $\mathrm{Zn}$ was obtained in the soil of Chencha. The results further showed that the concentration of $\mathrm{Cd}$ in all the study areas was below the detection limit. Furthermore, the overall mean value of macro, micro and toxic metals followed the patters as $\mathrm{Ca}>\mathrm{K}>\mathrm{Mg}$; $\mathrm{Fe}>\mathrm{Mn}>\mathrm{Zn}>\mathrm{Cu}$ and $\mathrm{Pb}, \mathrm{Cd}$, respectively. The results of the study also showed that all the metal concentrations in soil of Rubus steudneri Schweinf plant are higher than in the fruits, except for $\mathrm{K}$ and Cd metals.

One-way analysis of variance (ANOVA) test showed that all the metals, except $\mathrm{Mn}$ and $\mathrm{Ca}$, have insignificant variation in their concentration across the sampling sites and within the sampling site. Significant difference in metals concentrations between the wild edible plant fruits may be due to the bioavailability of metals in the soil and the accumulation ability of plants [7]. 
Furthermore, although, the concentrations of $\mathrm{Zn}$ (except at Chencha) and $\mathrm{Cu}$ in the fruit samples from any of the three sampling sites were found to be below the maximum limits set by the $\mathrm{FAO} / \mathrm{WHO}$. However, the concentration of $\mathrm{Cd}$ and $\mathrm{Pb}$ metals were found at elevated levels as compared to WHO/FAO. Thus, regular consumption of this fruit in higher amounts is not recommended, since $\mathrm{Cd}$ and $\mathrm{Pb}$ might cause for different health problems.

\section{Accumulation factor of metals from soil to plant}

Accumulation factor (AF) is a conventional method used to study the transfer of metals from soil to plant. It is calculated as a ratio of the concentration of a specific metal in the plant to the concentration of same metal in soil, both represented in same units. Higher AF values $(\geq 1)$ indicate higher absorption of metal from the soil by the plant and higher suitability of the plant for phytoextraction and phytoremediation. On the contrary, lower values indicate the poor response of plants towards metal absorption and the plant can be used for human consumption [32].

Metal accumulation factor from soil to plants is a key module for assessing human exposure to metals via the food chain. It has been used to investigate the human health risk. Table 8 summarizes the AF values for selected metals collected from the study area. The ranges of AF values were: $5.28-7.07,0.86-1.28,0.79-0.93,0.09-0.12,0.0025-0.01,0.22-0.92,0.20-043$, and $0.15-0.36$ for $\mathrm{K}, \mathrm{Ca}, \mathrm{Mg}, \mathrm{Mn}, \mathrm{Fe}, \mathrm{Cu}, \mathrm{Zn}$ and $\mathrm{Pb}$, respectively. The trend of AF for micro metals was found in the order of $\mathrm{Mg}>\mathrm{Cu}>\mathrm{Zn}>\mathrm{Mn}>\mathrm{Fe}$. Moreover, the $\mathrm{AF}$ value for $\mathrm{K}$ and $\mathrm{Ca}$ were higher than one, which indicates the plant has more accumulation of these metals as compared to others. This is might be due to high availability of these metals in the soil. On the other hand, the lower values indicate the poor response of plants towards metal absorption.

Generally, the factors such as the chemical form of elements, $\mathrm{pH}$, organic matter content, texture and cation exchange capacity (CEC) of the soil affects the loading and accumulation of metals in the soil. For instance, with increasing $\mathrm{pH}$, organic matter content, $\mathrm{CEC}$, and clay, the percentage, and availability of the metals are reduced. In addition, the existence of carbonate, sulfate, phosphate and sulfide in the soil creates an increase in the metal precipitation and consequently decrease their availability to the plants [32].

Table 8. Accumulation factor (AF) values for selected metals in the fruits at various sites.

\begin{tabular}{|c|c|c|c|}
\hline \multirow{2}{*}{ Metal } & \multicolumn{3}{|c|}{ Sampling sites } \\
\cline { 2 - 4 } & Chencha & Dega Damot & Fiche \\
\hline $\mathrm{K}$ & 7.07 & 5.93 & 5.29 \\
\hline $\mathrm{Mg}$ & 0.79 & 0.83 & 0.93 \\
\hline $\mathrm{Ca}$ & 0.86 & 1.28 & 0.98 \\
\hline $\mathrm{Mn}$ & 0.09 & 0.12 & 0.10 \\
\hline $\mathrm{Fe}$ & 0.009 & 0.003 & 0.003 \\
\hline $\mathrm{Cu}$ & 0.22 & 0.19 & 0.40 \\
\hline $\mathrm{Zn}$ & 0.43 & 0.31 & 0.20 \\
\hline $\mathrm{Pb}$ & 0.25 & 0.15 & 0.36 \\
\hline $\mathrm{Cd}$ & - & - & - \\
\hline
\end{tabular}

\section{Correlation coefficients of metals}

Pearson's correlation coefficients, shown in Table 9, were evaluated to investigate correlations between metal concentrations in the fruit samples [33]. The high correlation coefficient (near +1 or -1) means a good relationship between two variables, while its value around zero means no relationship between them at a significant level of $p=0.05$. It can be considered as strongly 
correlated, if $r>0.7$, whereas $r$ values between 0.5 and 0.7 shows moderate correlation between two different parameters [33].

Table 9. Pearson correlation coefficients between metals concentrations in Rubus steudneri Schweinf plant fruit samples.

\begin{tabular}{|c|c|c|c|c|c|c|c|c|c|}
\hline & $\mathrm{K}$ & $\mathrm{Mg}$ & $\mathrm{Ca}$ & $\mathrm{Mn}$ & $\mathrm{Fe}$ & $\mathrm{Cu}$ & $\mathrm{Zn}$ & $\mathrm{Pb}$ & $\mathrm{Cd}$ \\
\hline $\mathrm{K}$ & 1.00 & & & & & & & & \\
\hline $\mathrm{Mg}$ & -0.71 & 1.00 & & & & & & & \\
\hline $\mathrm{Ca}$ & -0.05 & 0.74 & 1.00 & & & & & & \\
\hline $\mathrm{Mn}$ & -0.66 & -0.07 & -0.72 & 1.00 & & & & & \\
\hline $\mathrm{Fe}$ & 0.43 & 0.33 & 0.88 & 0.88 & 1.00 & & & & \\
\hline $\mathrm{Cu}$ & -0.64 & 1.00 & 0.80 & -0.15 & 0.41 & 1.00 & & & \\
\hline $\mathrm{Zn}$ & 0.70 & 0.00 & 0.67 & -1.00 & 0.95 & 0.09 & 1.00 & & \\
\hline $\mathrm{Pb}$ & 0.20 & 0.55 & 0.97 & -0.87 & 0.97 & 0.62 & 0.84 & 1.00 & \\
\hline $\mathrm{Cd}$ & 1.00 & -0.74 & -0.09 & -0.63 & 0.39 & -0.68 & 0.67 & 0.16 & 1.00 \\
\hline
\end{tabular}

The correlation coefficients between metals in Rubus steudneri Schweinf plant fruits reflected very good associations for more metal of the relationships. Very strong correlations included $\mathrm{K} / \mathrm{Mg}, \mathrm{K} / \mathrm{Zn}, \mathrm{K} / \mathrm{Cd}, \mathrm{Mg} / \mathrm{Ca}, \mathrm{Mg} / \mathrm{Cu}, \mathrm{Mg} / \mathrm{Cd}, \mathrm{Ca} / \mathrm{Mn}, \mathrm{Ca} / \mathrm{Fe}, \mathrm{Ca} / \mathrm{Cu}, \mathrm{Ca} / \mathrm{Pb}, \mathrm{Mn} / \mathrm{Fe}$, $\mathrm{Mn} / \mathrm{Zn}, \mathrm{Mn} / \mathrm{Pb}, \mathrm{Fe} / \mathrm{Zn}$, and $\mathrm{Zn} / \mathrm{Pb}$. The lowest correlation coefficient of 0.00 with $\mathrm{Zn} / \mathrm{Mg}$ indicates no relation between these two metals. The correlation coefficient values for $\mathrm{K} / \mathrm{Cd}$, $\mathrm{Cu} / \mathrm{Mg}$, and $\mathrm{Zn} / \mathrm{Mn}$ were 1 . The remaining correlations of metals ranged under weak and medium associations.

\section{CONCLUSIONS}

This study determined the levels of essential metals ( $\mathrm{K}, \mathrm{Ca}, \mathrm{Mg}, \mathrm{Fe}, \mathrm{Zn}, \mathrm{Cu}, \mathrm{Mn}$ ) as well as toxic metals $(\mathrm{Cd}$ and $\mathrm{Pb})$ in the fruits of Rubus steudneri Schweinf and its underlying soil sampled at three different places in Ethiopia. The investigation of the metal levels revealed that for most of the metals considered, there is a direct relationship between the levels in the fruits and the soil in which the plant was grown. The study also showed that the metals were present at different concentrations in the samples from different sites. The level of $\mathrm{Cd}$ and $\mathrm{Pb}$ metals in all sampling sites exceeded the permissible levels by WHO/FAO. Therefore, frequent consumption of large amounts of fruits of Rubus steudneri Schweinf will be harmful to human health. The accumulation factor for $\mathrm{K}$ and $\mathrm{Ca}$ were found to be higher than one, which indicates that the fruit has high absorption capacity or bioavailability of these metals is high as compared to other metals.

\section{ACKNOWLEDGMENTS}

The authors express their gratitude to the Department of Chemistry, Addis Ababa University, Ethiopia for providing the laboratory facilities. Zelalem Pawlos would like to express his deepest gratitude to Kotebe Metropolitan University, Ethiopia for sponsoring his graduate study.

\section{REFERENCES}

1. Tuncturk, M.; Eryigit, T.; Sekeroglu, N.; Ozgokce, F. Chemical composition of some edible wild plants grown in Eastern Anatolia. Am. J. Essential Oils Nat. Prod. 2015, 2, 31-34.

2. Shaheen, S.; Ahmad, M.; Haroon, N. Edible wild plants: A solution to overcome food insecurity. Springer Int. Publ. 2017, 6, 41-57. 
3. Islary, A.; Sarmah, J.; Basumatary, S. Proximate composition, mineral content, phytochemical analysis and in vitro antioxidant activities of a wild edible fruit (Grewia sapida Roxb. ex DC.) found in Assam of North-East India. J. Invest. Biochem. 2016, 5, 21-31.

4. Umoh, V.A.; Peters, E. The relationship between lung function and indoor air pollution among rural women in the Niger Delta region of Nigeria. Lung India 2014, 31, 110-115.

5. Alemayehu Abiye, T.; Sulaiman, H.; Hailu, A. Metal concentration in vegetables grown in the hydrothermally affected area in Ethiopia. J. Geogr. Geol. 2011, 3, 86-93.

6. Mustapha, H.I.; Adebayo, O.B. Heavy metals accumulation in edible part of vegetables irrigated with untreated municipal wastewater in tropical savannah zone, Nigeria. Afr. $J$. Environ. Sci. Technol. 2014, 8, 460-463.

7. Boke, A.; Megersa, N.; Teju, E. Quantitative determination of the heavy metal levels in the wild edible plant parts and their corresponding soils of the Central and Western Regions of the Oromia State, Ethiopia. J. Environ. Anal. Toxicol. 2015, 5, article no. 5. DOI: 10.4172/2161-0525.1000299.

8. Feng, X.D.; Dang, Z.; Huang, W.L.; Yang, C. Chemical speciation of fine particle bound trace metals. Int. J. Environ. Sci. Techenol. 2009, 6, 337-346.

9. Takáč, P.; Szabová, T.; Kozáková, L.; Benková, M. Heavy metals and their bioavailability from soils in the long-term polluted Central Spiš region of SR. Plant Soil Environ. 2009, 55, $167-172$.

10. Fullerton, D.G.; Bruce, N.; Gordon, S.B. Indoor air pollution from biomass fuel smoke is a major health concern in the developing world. Trans. Royal Soc. Trop. Med. Hygiene 2008, $102,843-851$.

11. Belayneh, T.; Atnafu, Z.; Madhusudhan, A. Determinations of the level of essential and nonessential metals in rice and soil samples. Int. J. Modern Chem. Appl. Sci. 2015, 2, 65-72.

12. Addis, G.; Urga, K.; Dikasso, D. Ethnobotanical study of edible wild plants in some selected Districts of Ethiopia. Human Ecology 2005, 33, 83-118.

13. Balemie, K.; Kebebew, F. Ethnobotanical study of wild edible plants in Derashe and Kucha Districts, South Ethiopia. J. Ethnobiol. Ethnomed. 2006, 2, article no 53. DOI: 10.1186/1746-4269-2-53. 2006.

14. Guyu, D.F.; Muluneh, W.-T. Wild foods (plants and animals) in the green famine belt of Ethiopia: Do they contribute to household resilience to seasonal food insecurity?. Forest Ecosystems 2015, 2, article no. 34. DOI: 10.1186/s40663-015-0058-z.

15. Yineger, H.; Yewhalaw, D.; Teketay, D. Ethnomedicinal plant knowledge and practice of the Oromo ethnic group in southwestern Ethiopia. J. Ethnobiol. Ethnomed. 2008, 4, article no. 11. DOI: 10.1186/1746-4269-4-11.

16. Kefalew, A.; Asfaw, Z.; Kelbessa, E. Ethnobotany of medicinal plants in Ada'a District, East Shewa Zone of Oromia Regional State, Ethiopia. J. Ethnobiol. Ethnomed. 2015, 11, article no. 25. DOI: 10.1186/s13002-015-0014-6.

17. Bednarek, W.; Tkaczyk, P.; Dresler, S. Content of heavy metals as a criterium of the quality of strawberry fruit and soil properties. Polish J. Soil Sci. 2006, 39, 165-174.

18. Lulekal, E.; Asfaw, Z.; Kelbessa, E.; Damme, P.V. Wild edible plants in Ethiopia: A review on their potential to combat food insecurity. Afrika Focus 2011, 24, 71-121.

19. Mesfin, F.; Seta, T.; Assefa, A. An ethnobotanical study of medicinal plants in Amaro Woreda, Ethiopia. Ethnobotany Res. Appl. 2014, 12, 341-354.

20. Tadesse, M.; Hunde, D.; Getachew, Y. Survey of medicinal plants used to treat human diseases in Seka Chekorsa, Jimma Zone, Ethiopia. Ethiop. J. Health Sci. 2005, 15, 89-107.

21. Aregahegn, A.; Chandravanshi, B.S.; Atlabachew, M. Mineral contents of fruits of cactus pear (Opuntia ficus indica) grown in Ethiopia. Acta Hort. (ISHS), 2013, 979, 117-126. 
22. Endalamaw, F.D.; Chandravanshi, B.S. Levels of major and trace elements in fennel (Foeniculum vulgari Mill.) fruits cultivated in Ethiopia. Springer Plus 2015, 4, article no. 5. DOI: 10.1186/2193-1801-4-5.

23. Yami, S.G.; Chandravanshi, B.S.; Wondimu, T.; Abuye, C. Assessment of selected nutrients and toxic metals in fruits, soils and irrigation waters of Awara Melka and Nura Era farms, Ethiopia. Springer Plus 2016, 5, article no. 747. DOI: 10.1186/s40064-016-2382-3.

24. Jemaneh, D.; Chandravanshi, B.S. Mineral contents of Ethiopian red and green apple fruits: A comparison with WHO/FAO standards. Chem. Int. 2021, 7, 112-122.

25. Pawlos, Z.; Chandravanshi, B.S.; Yohannes, W.; Embiale, A. Levels of selected metals in Ficus sur Forssk fruit and soil of the plant grown in different parts of Ethiopia. SINET: Ethiop. J. Sci. 2021, 44, 1-12.

26. Mekassa, B.; Chandravanshi, B.S. Levels of selected essential and non-essential metals in seeds of korarima (Aframomum corrorima) cultivated in Ethiopia. Braz. J. Food Technol. 2015, 18, 102-111.

27. Hagos, M.; Chandravanshi, B.S. Levels of essential and non-essential metals in fenugreek seed (Trigonella Foenum-Graecum L.) cultivated in different parts of Ethiopia. Braz. J. Food Technol. 2016, 19, article no. e2015059.

28. Nweke, I.A.; Nsoanya, L.N. Soil pH an indices for effective management of soils for crop production. Int. J. Sci. Technol. Res. 2013, 2, 132-134.

29. Ratul, A.K.; Hassan, M.; Uddin, M.K.; Sultana, M.S.; Akbor, M.A.; Ahsan, M.A. Potential health risk of heavy metals accumulation in vegetables irrigated with polluted river water. Int. Food Res. J. 2018, 25, 329-338.

30. Ling, S.H.; van Eeden, S.F. Particulate matter air pollution exposure: Role in the development and exacerbation of chronic obstructive pulmonary disease. Int. J. Chronic Obstr. Pulmonary Disease 2009, 4, 233-243.

31. Codex Alimentarius Commission, Joint FAO/WHO food standards programme codex committee on contaminants in foods, Fifth Session, The Hague, The Netherlands, 2011.

32. Mirecki, N.; Agič, R.; Šunić, L.; Milenković, L.; Ilić, Z.L. Transfer factor as indicator of heavy metals content in plants. Fresenius Environ. Bull. 2015, 24, 4212-4219.

33. Rakesh Sharma, M.S.; Raju, N.S. Correlation of heavy metal contamination with soil properties of industrial areas of Mysore, Karnataka, India by cluster analysis. Int. Res. J. Environ. Sci. 2013, 2, 22-27. 